\title{
REAPING THE MINERAL WEALTH: WHAT ARE THE LESSONS FOR NIGERIA? https://doi.org/10.47743/jopafl-2021-19-08
}

\author{
Sylvia Halima ADETORO \\ University of Dundee \\ Ife, Nigeria. \\ sylvia.adetoro@yahoo.co.uk \\ David O ADETORO \\ University of Glasgow, University of Dundee, Ife, Nigeria American University of Nigeria, \\ Yola, Nigeria \\ david.adetoro@aun.edu.ng
}

\begin{abstract}
Presently, income from petroleum resources accounts for 95\% of revenue accruing from exports to the Nigerian Government. Nigeria is however, rich in diverse minerals, with 34 mineral types in 450 locations, which if well harnessed can provide a new stream of income. The establishment of a Ministry of Solid Minerals Development is an indication of government's preparedness to explore the opportunities presented by this sector of the economy. The question, which becomes apparent, is whether the fiscal regime for mineral exploration is well formulated to yield maximum and sustainable benefits for the parties involved. Bearing in mind the existence of mature mining regions all over the globe, this paper draws from their experiences, including likely pitfalls, with the aim of providing suggestions for policy makers in Nigeria in order to guarantee an optimal utilisation and sustenance of the benefits accruable from the sector.
\end{abstract}

Keyword: mineral wealth, resources, royalties taxation and sustainable development

\section{Introduction}

Resource-rich developing countries rely on incomes accruing from the exploitation of the hydrocarbons occurring in their territories. While ownership and control of these substances are usually vested in the state (Okonkwo, 2017), with a few country-specific exceptions, the capital intensive nature as well as the high technical requirements of the extractive industry allows the participation of individuals and companies other than the governments of these countries, at a cost which often involves being subjected to some form of tax regimes (Smith, 2000). Taxation is therefore is one of the traditional means by which the exploitation of a public asset is paid for (Garnaut and Ross, 1983). Governments seek to attract the needed investment and to obtain from them, the maximum revenues possible without discarding the principles of sustainable development (Sarma and Naresh, 2001). Achieving this balance lies at the heart of a successful fiscal regime and determining what substances and commodities would bring in the much-needed income provides the basis for design. More than ever, countries with a high dependency on the exportation of petroleum resources are seeking means to diversify their income stream (Aigbedion and Iyayi, 2007). This is not unconnected to the volatility of international prices for crude oil and its ripple effects on Governments' revenue and ultimately, budgets and spending (the recent fall of world prices for crude have led to uncertainties and a rethink of the wisdom in sole reliance on incomes from it). Nigeria is one such country with petroleum resources 
accounting for about $95 \%$ of its total income from exports. This notwithstanding, Nigeria is similarly rich in diverse solid minerals with 34 different minerals occurring in 450 locations (Mobbs, 2001). The Nigerian government has given an indication of its preparedness to explore the opportunities presented by this sector of the economy. The question, which becomes apparent, is whether the fiscal regime for mineral exploration is well formulated and able to yield the expected benefits for all parties involved. Further, it is not evident whether one can yet lay hold of any official geological mapping of the solid mineral deposits in Nigeria. In addition, there are cases of illegal mining and conspiracy theories to this extent. Bearing in mind the existence of mature mining regions all over the globe and their different levels of successes and failures, this paper evaluates the present state of the Nigerian Mining industry with particular emphasis on taxation. Additionally, it draws wisdom from different countries and attempts to provide lessons for policy makers in designing the most appropriate fiscal regime for solid minerals in Nigeria.

\section{Why Tax?}

Taxing of minerals is important to governments and its effects important to the taxpayer, which in many cases are companies. The effects of taxation on companies would influence their decision-making on the kinds of projects or the sectors in which they invest and the countries for choice of investments. This is because companies are established for the primary goal of maximising profits and must therefore channel their investment decisions towards this goal. However, governments have several reasons for levying taxes and these can be classified into two major categories. These are discussed below:

\section{Revenue Mobilisation}

The political obligation and social responsibilities' role of government require that it raise money to effectively function and implement its policy objectives. Mineral taxation provides a means of achieving this goal. Setting low taxes may attract the needed investment but rob the country of adequate revenues to justify the mineral extraction. A responsibility is therefore placed on governments to retain investments, attract new investments and at the same time, devise a means of maximising incomes (Jenkins, 2003). A strive towards this balance is influenced by several factors which include but are not limited to the instruments that are adopted for taxation and the available tax allowances. These form the basis for design of the fiscal regime that is finally chosen in for each country.

\section{Influencing the Taxpayer}

The obligations of governments extend to their ability to use their position to influence the behaviour of persons conducting business within its territory. Its ability to attract investors is one of such means. Most important is its role in monitoring and controlling of attitudes of investors to reinvest some of their income rather than repatriate all of it; to take cognisance of and adhere to environmental best practices, and to increase their investment levels. Thus, tax management like most core management issues require transparent and consistent application of taxation methods for optimum results. 


\section{What are the Available Options?}

It is not uncommon for governments to design a special regime for the taxation of certain sectors of its economy (Toye, 1978). Though other revenue - yielding activities of an economy are generally subject to taxation, certain distinctive characteristics of the minerals sector give rise to considerations for designing a special regime. One of these characteristics is the cost of extracting the minerals and the risk of loss that can arise in the event of failure. Closely connected to its capital intensive nature is the issue of location. The geographical location of most mineral deposits increases the risk level that is already inherent in the business. Other reasons are the existence of fixed and immobile assets in remote areas; the need for special technological knowledge; non-renewable and finite nature of the resources; unpredictability and cyclic nature of international market; social economic impacts resulting from loss of incomes when mines take over arable land amongst others. In fact, risk associated with location is most often of higher significance than most other risks like political risk.

\section{Income Tax}

Income tax is that tax that is levied on the profit income of the taxpayer. It is taxed after the profits have been determined. The taxable profit is usually that remaining income after operating costs and allowances are subtracted from the total revenue of the company (Kumar, 1995). Such taxes are usually called 'corporate tax'. It should be noted that income tax is the tax system commonly used in the mining industry, and it revolves around two major indices that characterises policy decision. They are as follows: (Cordes, 1996).

- Selection of tax rate

- Defining and determination of various operational variables.

By selection of tax rates, the government will have to employ the various tools available in other to determine the taxable income. On the other hand, the government will have to determine the extent of the operations throughout the mining activity to determine the value of the income to come up with a conclusive income tax. This would, of course, require available tax expertise, as such, taxes are not easy to administer.

\section{Royalties}

Royalties are levies paid by the mining, either upon the attainment of particular landmark in the project or on the value of the mineral product, i.e., ad valorem or both. This tax structure is easy to administer because they are usually pre-determined from the start of the mining project, and so are determined as the company meets those thresholds. They may not be that common in the mining industry compared to the income tax, as governments are careful to avoid them to encourage investment in the mining industry.

\section{Where is the Nigerian Mining Sector?}

The Nigerian mineral sector has undergone several stages of development. The petroleum sub-sector, which had been in the public eye for many decades, is not the focus of this paper. Rather, it is the solid minerals sector, which is presently assuming a more central stance that is being considered. The historical perspectives as well as the trends that have developed over time provide a starting point for creating an effective tax environment for the future. 


\section{Historical Perspective}

Mineral operations in Nigeria first started in 1904 and a Minerals Act aimed at regulating the sector was enacted in 1946. With the variety in the mineral types and the spread in terms of locations, Nigeria was and still is described as having the highest concentration of varieties of solid minerals in Africa (Ezekwesilli, 2005). The discovery of oil in the late 1950s however led to a complete neglect of the rich potentials available in the mining sector. Until recently, Nigeria did not have a clear-cut approach to taxing its solid minerals but rather took the role of owner and operator (Adeniji, 2007). This contributed immensely to the under-utilization of the sector, especially low level of income generated from the sector compared to its potentials. This phenomenon is known as the 'Dutch Disease'. Revenue from exports is an important source of wealth for governments but is not the focus of this paper. Although government made concerted efforts to develop an attractive fiscal regime for its solid minerals, revenues from the sector contributed a paltry $0.3 \%$ to the overall national income.

The mineral sector has remained sparsely developed mainly due to the oil boom, which changed the attitude and the vocabulary reference to minerals in Nigeria to always meaning oil and gas prospecting and development. Though there was an acknowledgement of the rich mineral deposits, government bias for the seemingly more lucrative oil sector cast a shadow on the prospect for vigorous pursuit of the 'buried wealth'. This bias was naturally characterised by a period of lack of zeal in developing a coherent approach to taxation in this regard. Artisan and illegal mining activities were prevalent, further affecting projected expectations on government income, and failing to deliver desired results.

The later part of the 1990s saw a general drive to attract investment to a seemingly stable Nigeria, and this led to a move towards reviving the hitherto neglected solid minerals sector. Part of the reform drive led to the promulgation of the Minerals Act of 1999, which did not achieve the desired goals of acting as a stimulus to investors and increasing the financial benefits to the country. The limitation in terms of its success was traceable to several factors, which include the fiscal terms and a lack of adequate geological information on the existing minerals. The shortfall resulting from the lapses caused the enactment of the 2007 Minerals Act.

\section{Developing Trends}

It has been identified that while in developing countries it is usual that the fiscal regime for minerals to consist of contractual arrangements as well as general state laws and regulations, those of developed countries are usually spelt out in general legislation (Kumar, 1995). It is instructive to note that the trend in Nigeria leans closer to the position obtainable in the developed countries. The 2007 Minerals and Mining Act is a comprehensive law, clearly providing a special tax regime for minerals. Its main features are captured below. The International Council of Mining and Metals' report on the challenges of mineral wealth (Mineral Taxation Regimes, 2009) suggests that while the fiscal regime for the minerals sector of most countries have undergone changes in recent times, these changes were triggered by a need to improve performance in terms of revenue realisation and maximisation, rather than for the aim of reverting to tax systems that are predominantly regressive. This argument is buttressed by an inclusion in the Nigerian law, of incentives, which are targeted at attracting private investors (Mobbs, 2009). 
At first glance, the new Minerals Act seems to have incorporated the criteria that should have investors falling over themselves to invest. These include the following:

*Tax relief period of three years renewable for a further two years period *95\% CAPEX deductible as capital allowance from assessable profits

*Annual capital cost indexation of 5\% of mines starting production within five years of the commencement of the Act

*Losses may be carried forward indefinitely

*Liberal exchange control regime

Two years down the line, the question is: are there results or at least prospects that should create an assurance of better times to come in the sector? The saying that no man is an island is also applicable to countries. Studying and applying the lessons available from other countries help history to remain history rather than repeating itself in present times.

\section{Lessons from Other Countries}

The major advantage existing for a developing country like Nigeria is the fact that creating the appropriate fiscal policy for solid minerals is not a new phenomenon, but one that has received attention and comment over the decades. It is inevitable to measure success on a scale of a system's ability to attract and sustain veritable income. This section therefore presents a summary of two countries' experiences in the sector with the aim of providing a platform for achieving success in Nigeria.

\section{Brazil}

Brazil's early struggle with success in its mining industry is a classic example of the effects that a fiscal and regulatory regime can have on productivity. Productivity in this regard is used in terms of achieving expected results. Despite the existence of proven mineral reserves and a high potential for further discovery, it failed to attract foreign investment and thereby income from that source (Andrews-Speed, 1996). This does not however imply that foreign investments are the only basis of measuring economic success. The importance of foreign investments to an economy cannot be overemphasised and extend to the fabric of both developing and developed countries (OECD, 2002). This is even more so for developing countries of which Nigeria is one. With a study of international regimes for mining revealing a high tax rate and a regressive taxing system, Brazil was described as 'one of the most unfavourable' among the major mining nations. Another important factor that worked against it at the time was a perception of the risk involved in conducting business in Brazil. Regardless of whether this was a true position or not and because taxation does not work in isolation but incorporates the whole situation prevailing within a country, it generally deterred a healthy investment environment. The issues, which prevailed against Brazil's initial success, were multifaceted. Amongst these was the fact that though it is settled that the special features of the mining industry qualifies it for a special tax regime, only few of its applicable tax regulations were industry-specific taxes. The downward trend in the investment climate coincided with reforms and constitutional amendments, which along with others allowed municipalities and provinces to tax mineral exploitation. A federal tax system was in operation and taxes and other levies were paid at the federal, state and municipal levels not to mention a form of royalty paid to landowners. This arrangement was very cumbersome, time consuming and 
generally discouraging to prospective investors. It was reported that it would take 2,600 hours for a firm to comply with tax requirements in Brazil. Further regulatory reviews and a massive campaign led to a dramatic turn of events. Specifically, were the opening of the minerals sector to foreign capital; a decline in the tax burden due to reduction in tax rates; tax exemptions; creating special incentives for less developed regions amongst others (Fernandez, 1997). Within one year, the investment levels in monetary terms moved from USD73 million to USD100 million with about 40 new foreign companies carrying out surveys and many more seeking to partner with local holders of existing mineral rights. This study does not conclude that everything has become settled and perfect with the Brazilian mineral sector. A lot still needs to go into finalizing recommendations, implementing set rules and the adding the flexibility required to adapt to changing circumstances. The main lessons to be drawn from the Brazilian experience is in the fact that the changes to the sector were not limited to the fiscal regime of the minerals industry, but rather adopted a holistic approach by considering a wider range of circumstances which in essence affect the sector and resulting in the level of success attained.

\section{Canada}

Evidence that a tax system can be very complicated and yet fair is clearly reflected in the Canadian fiscal regime for minerals (Parsons, 1995). A study of the success recorded in such a complex system is important particularly in equipping Nigeria for the challenges inherent in managing states and communities that host the mineral resources and avoid the present challenges emanating from conflicts in its oil-rich Niger Delta region. Nigeria's potential in oil and gas exploration is being thwarted by conflicts and disturbances in the oil producing regions, the Niger Delta, leading to fear and a loss of confidence by investors due to reduced production rates. Emphasis is being laid on the avoidance of a similar trend in the solid minerals sector. The taxes in Canada though multiple, are mostly income based with additional incentives and this on its own presents an incentive to investors. The Canadian constitution places substantial powers on the provinces and therefore gives them a right to tax. An opportunity also exists for the communities to compete against each other for investments, which inevitably improves the investment climate for the whole country. Taxation of minerals is generally characterised by three separate levels of income tax to wit: federal income tax; provincial income tax and provincial mining tax or royalty as well as federal goods and service tax; federal and provincial capital taxes; provincial water tax; provincial water taxes; provincial payroll taxes; provincial and municipal property tax. There is wisdom in creating specific tax rules for different mineral types. This has been tested in Canada where the mining regulation differentiates between industrial and non industrial minerals and treats them differently (Otto, 1992). This gives an opportunity to a prospective investor to decide ahead of time, the line of mining business that is most suited for its investment capacity. Lessons abound from the minerals taxation regime in Canada, but this does preclude the fact that its complexity is not one that can be easily and completely replicated in developing countries. Recognition by Canada of the great benefits it derives from the sector causes it to take as a very serious business while improving on its workability. 


\section{Recommendations for the Way Forward}

Nigeria's eagerness to earn reasonable income and create sustainable wealth from its solid minerals should serve as a motivation for learning from the practices of more developed mining regions, which have been presented in the foregoing section. Its ability to sift the wheat from the chaff and to arrive at a most appropriate fiscal regime that is both attractive and workable is a clear indicator for achieving success. The aim of this section is to draw lessons from Brazil and Canada.

\section{Applying the Models}

Like every system, the Brazilian fiscal regime for minerals is not perfect. One of the things it has in common with Nigeria is the perception of the risk by the outside world. Persistent change of governments and recent oil and gas exploration disruptions resulting from actions of dissatisfied host communities has also earned Nigeria that reputation (Ross, 2003). No company sets out to conduct business where its revenues are not secure. While the allowing the municipals an opportunity to tax is not a welcome approach, getting the communities involved with other activities consequential to the exploration and development of the resources will no doubt help to forge a friendly and inclusive relationship among the parties. However, this has to be balanced with the economic objective and long-term goals of the parties especially concerning issues like sustainable use and corporate image of the main actors.

\section{Managing the Revenues}

Most federal systems are usually faced with the problem of effectively managing revenues from their natural resources. The two methods, which are available for managing revenues, is either that of fiscal decentralisation or sharing of revenues. Nigeria operates a federal tax system where the bulk of the taxes applicable to mining are collected by the Federal government and then distributed based on the budgets emanating from its 36 states and Federal Capital Territory (FCT). Most of the agitations that have become a daily mantra among politicians and citizenry, especially from the Niger Delta of Nigeria are informed by their dissatisfaction and expectation of more income from the share of the tax income and wealth generated from the mineral deposits in their respective areas. The inability to devise a satisfying sharing formula that leads to a viable creation of wealth in the affected areas has continued to put exploitation and mineral development at greater risks that have affected not just capital resources but human capital at an alarming level.

\section{Conclusion}

An important message, which is central to this paper, is the fact that an abundance of mineral resource endowment does not automatically bring wealth to a nation. Solid minerals are seated deep within the earth's crust and for effective utilisation; they require pragmatic contractual arrangement based on well-defined rules and law to be implemented on a core total quality management principle. Although, the analysis and views expressed in this paper will not be a total panacea for other social developments or infrastructure inadequacy in Nigeria, it will go a long way to allow the citizenry to enjoy on a sustainable level, the proceeds of their natural wealth that had hitherto appeared like an economic mirage to them. Learning is a never-ending process and opportunities to maximally utilise 
available the lessons of other regions, avoiding their failures and seeking a proper more enlightenment from their wealth of wisdom, will place Nigeria amongst the top solid minerals in the world.

\section{References}

1. $\quad$ Aigbedion, I., Iyayi, S.E., Diversifying Nigeria’s Petroleum Industry, in 2 (10) International Journal of Physical Sciences, 264 (2007)

2. Andrews-Speed, P., \& Rogers, C. D. (1999). Mining taxation issues for the future. Resources Policy, 25(4), 221-227. https://doi.org/10.1016/S0301-4207(99)00029-X

3. $\quad$ Andrews-Speed, C.P., Fiscal Systems for Mining in Countries with Mineral Resources and their effect on Commercialisation of Minerals: With Special Reference to Brazil CEPMLP Seminar Paper SP 25 (Center for Energy Petroleum, Energy and Mineral Law and Policy, University of Dundee, 1996)

4. Bercu, Ana-Maria; Paraschiv, Gigel; Lupu, Dan. Investigating the energy-economic growthgovernance nexus: Evidence from central and eastern european countries. Sustainability, 2019, 11.12: 3355, https://doi.org/10.3390/su11123355

5. Blanc, G.P. and Parsons, R.B., Mineral Royalties in the Asia Pacific area: a Comparative Review, in 4 International Energy Law and Taxation Review, 81(2003)

6. $\quad$ Ezekwesilli, O., Nigeria: Promoting Wealth through Solid Minerals (24October 2005), Published at http:www.africafiles.org/article.asp?ID=10063\&ThisURL=,/resource\%Extraction (last visited on $5^{\text {th }}$ August 2020)

7. Garnaut, R., and Ross, A.C., Taxation of Mineral Rents, (Oxford: Clarendon Press 1983)

8. ICMM, Mineral Taxation Regimes: A Review of Issues and challenges in their design and application, a joint study conducted by the International Council of Mining and Metals, February 2009, Common Wealth Secretariat.

9. Jenkins, G.P., et al., Taxation and Economic Development in Taiwan (Cambridge: Harvard University Press, 2003)

10. Kumar, R., Mine Taxation: The Evolution of Fiscal Regimes, in Taxation of Mineral Enterprises Otto J. M., ed., London: Graham \& Trotman Ltd, 1995

11. OECD, Foreign Direct Investment for Development: Maximising benefits Minimising costs. Published athttp://www.oecd.org/dataoecd/47/51/1959815.pdf. (last visited on 5th August 2020)

12. Okonkwo, T., Ownership and Control of Natural Resources under the Nigerian Constitution 1999 and Its Implications for Environmental Law and Practice’ International Law Research; Vol. 6, No. 1; 2017

13. Otto, J., Mineral Sector Taxation Methods: A Global Review in Mineral Industry Taxation Policies for Asia and the Pacific (United Nations, New York: 1992)

14. Parsons, R., Mineral Taxation in Canada in Otto J. M., ed., Taxation of Mineral Enterprises (London: Graham \& Trotman Ltd, 1995)

15. Ross, M.L., Nigeria's Oil Sector and the Poor (May 2003) Published at http://www.sscnet.ucla.edu/polisci/faculty/ross/NigeriaOil.pdf. (last visited on 5th August 2020

16. Toye, J.F.J. ed., Taxation and Economic Development: Twelve Critical Studies ( London: Frank Cass and Company, 1978)

17. Sarma, J.V.M. and Naresh, G., Mineral Taxation around the World: Trends and Issues, in Asia Pacific Tax Bulletin, 2 (2001)

18. Smith, E.E., et al., International Petroleum Transactions, $2^{\text {nd }}$ ed., (Denver: Rocky Mountain Mineral Law Foundation, 2000)

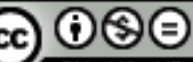

This article is an open access article distributed under the terms and conditions of the Creative Commons Attribution - Non Commercial - No Derivatives 4.0 International License. 